\title{
PENINGKATAN KUALITAS PENDIDIKAN DI PERGURUAN TINGGI MELALUI TOTAL QUALITY MANAGEMENT (TQM) DALAM MENYONGSONG MASYARAKAT EKONOMI ASEAN (MEA)
}

\author{
Aprina Chintya \\ Sai Wawai Institute \\ aprinachintya64@gmail.com
}

\begin{abstract}
Total Quality Management (TQM) is an effort done by college to improve their management quality in achieving the goals. TQM related to quality system consist of planning system quality, controlling system quality, and improving system quality. Hence, in this research, the researcher manages to explain the improving education quality at Collage through TQM in welcoming MEA. This is descriptive literature review research. The source of the data is taken from books and others review related to improving education quality at Collage through TQM. This research employs documentation as data collection technique and content analysis to analyze the data which use the procedure to make the conclusion. The result shows that when TQM applied at collage continuity and consistently, the quality of graduates will increase, in this case they are capable to compete in industry field.
\end{abstract}

Keywords: quality, Collage, TQM, MEA

\begin{abstract}
Abstrak
Salah satu usaha perguruan tinggi yang diharapkan dapat meningkatkan mutu pengelolaanya untuk mencapai tujuannya adalah dengan menerapkan Total Quality Management(TQM).TQM ini akan berhubungan dengan sistem kualitas yang terdiri dari : perencanaan sistem kualitas, pengendalian sistem kualitas, dan peningkatan sistem kualitas. Untuk itu, dalam penelitian ini peneliti berupaya untuk menjelaskan peningkatan kualitas pendidikan di perguruan tinggi melalui TQM dalam menyongsong MEA. Penelitian ini adalah penelitian pustaka yang bersifat deskriptif. Sumber data yang digunakan dalam penelitian adalah sumber data sekunder berupaya buku-buku dan literatur terkait dengan peningkatan kualitas pendidikan di perguruan tinggi melalui TQM dalam menyongsong MEA. Tehnik pengumpulan data dilakukan melalui dokumentasi sedangkan analisa data dalam penelitian ini dilakukan dengan content analysis, yakni dengan memanfaatkan seperangkat prosedur untuk menarik kesimpulan yang shahih dari sebuah buku atau dokumen. Hasil penelitian menunjukkan bahwa Apabila TQM pada perguruan tinggi diterapkan dan dijalankan secara kontinyu dan konsisten maka kualitas lulusannya akan semakin meningkat, dalam arti telah mampu dan siap bersaing untuk memasuki dunia kerja industri.
\end{abstract}

Kata kunci: kualitas, perguruan tinggi, TQM, MEA

\section{Pendahuluan}

Masyarakat Ekonomi Asean (MEA) 2015 atau Asean Economic Community (AEC) 2015 merupakan bentuk kerjasama baru antar negara-negara di regional ASEAN yang bertujuan untuk meningkatkan sektor perekonomian dan stabilitas politik serta keamanan. MEA 2015 akan diikuti oleh 10 negara yaitu Indonesia, Myanmar, Thailand, Malaysia, Singapura, Brunei Darussalam, 
Philipina, Laos, Kamboja dan Vietnam. MEA merupakan gabungan negaranegara di Asia Tenggara yang sepakat melakukan integrasi ekonomi berupa rancangan dan implementasi serangkaian peraturan/kebijakan khusus yang bertujuan untuk meningkatkan pertukaran barang maupun faktor produksi antar negara. Sebagai negara yang telah bergabung dengan MEA, maka Indonesia wajib dan harus siap untuk menghadapi MEA sehingga Indonesia harus meningkatkan sumber daya manusia yang memadai serta berani bersaing di lingkungan MEA. ${ }^{1}$

Komunitas Asean 2015 atau yang dikenal dengan MEA diharapkan mampu menyokong kegiatan- kegiatan yang dilakukan oleh negara ASEAN dengan berlandaskan 3 (tiga) pilar yaitu politik keamanan (politico-security cooperation), kerjasama ekonomi (economic cooperation) serta kerjasama sosial budaya (socio-cultural cooperation). Kegiatan di negara Asia Tenggara ini dianggap kurang menguntungkan negara-negara yang masih "merangkak" pada bidang ekonomi dan teknologi, seperti salah satunya negara Indonesia yang masih kalah bersaing dengan beberapa negara Asean seperti Singapura dan Malaysia. ${ }^{2}$

Indonesia dikenal sebagai negara dengan sumber daya alam dan sumber daya manusia yang melimpah. Namun ironisnya, Indonesia masih kekurangan tenaga kerja ahli dan terdidik serta kurangnya penguasan teknologi.itulah sebabnya Indonesia menjadi sasaran empuk bagi negara-negara maju untuk mengeksploitasi sumber-sumber daya Indonesia dengan biaya yang murah.

Salah satu cara mengatasi hal tersebut adalah dengan pendidikan. Pendidikan mempunyai peranan yang sangat penting terhadap kemajuan suatu bangsa. Banyak pendapat mengatakan bahwa kemajuan suatu Negara dapat dilihat dari kemajuan pendidikannya. Pada Pasal 20 Ayat 2 Undang-Undang Republik Indonesia Nomor 20 Tahun 2003 tentang Sistem Pendidikan Nasional menyatakan bahwa "Perguruan tinggi berkewajiban menyelenggarakan pendidikan, penelitian, dan pengabdian kepada masyarakat."

Pendidikan memegang peranan penting dalam membangun sumber daya manusia yang kompetitif dan mampu bersaing dengan negara lain. Oleh karena itu dalam menghadapi MEA, pendidikan harus mampu mempersiapkan sumber daya manusia yang terampil dalam menghadapai tantangan serta perubahan yang terjadi didunia pendidikan, seperti menjamurnya lembaga pendidikan asing, standard dan orientasi pendidikan yang bertaraf internasional, serta menjamurnya pasar tenaga kerja yang akan dibanjiri oleh tenaga kerja asing.

Melalui pendidikan akan lahir manusia sebagai human capital, yang daya produksinya secara residual tidak kalah dengan faktor produksi. Tingginya rata-

1 Chici Andriani, Mahasiswa dan Perguruan Tinggi dalam Era ASEAN Economic Community 2015, Seminar Ekonomi Manajemen dan Akutansi (SNEMA) Fakultas Ekonomi Universitas Negeri Padang, h. 284. Dapat Diakses Melalui http://fe.unp.ac.id/.

2 Ibid.

RI'AYAH, Vol. 01, No. 01 Januari-Juni 2016 
rata pendidikan penduduk berkorelasi secfara ekonomi dnegan pertumbuhan ekonomi suatu negara. Pembangunan pendidikan merupakan salah satu kunci utama bagi percepatan dan pertumbuhan ekonomi negara pada umumnya dan kesejahteraan penduduk pada khususnya. Menyiapkan SDM yang mumpuni harus diakui jauh lebih penting daripada membeli tehnologi atau penanaman modal fisik. ${ }^{3}$

Mahasiswa merupakan elemen yang mendapatkan pengaruh yang besar dengan diberlakukannya MEA. Mahasiswa harus mampu meningkatkan kualifikasinya dalam menghadapi MEA khusunya untuk bersaing dan berkompetisi di dunia kerja. Mahasiswa tidak hanya diharapkan mencari IPK semata, melainkan juga menambah dan meningkatkan kompetensi yang nantinya diharapkan akan memiliki skill yang cukup dalam menghadapi MEA. Mahasiswa harus mengausai hard skill dan soft skill untuk mendapatkan karir yang lebih baik. Mahasiswa harus sadar akan pentingnya soft skill terutama dalam kemampuan berbahasa asing dan bakat-bakat lain. Mahasiswa harus sadar akan pentingnya soft skill terutama dalam kemampuan berbahasa asing dan bakat-bakat lain.

Melihat peran yang harus dilakoni oleh mahasiswa dalam menghadapi MEA 2015, perguruan tinggi sebagai lembaga yang menaungi pendidikan mahasiswa memiliki peran yangsangat penting dalam membantu mahasiswa dalam menghadapi MEA. Perguruan tinggi merupakan lembaga pendidikan yang memiliki visi dan misi dalam melaksanakan proses pembelajaran harus mengaplikasikan Tri Dharma perguruan tinggi yang terdiri dari pendidikan, penelitian dan pengabdian kepada masyarakat untukmelahirkan sumber daya manusia yang intelek, kritis dan peduli dan berakhlak mulia. Sehingga dalam memenuhi pelaksanaan Tri Dharma perguruan tinggi tersebut, mahasiswa sebagai unsur dalam perguruan tinggi juga harus tahu dan paham dengan apa yang dimaksud dengan Tri Dharma perguruan tinggi. tersebut.

Untuk menghadapi tantangan dalam Masyarakat Ekonomi Asean (MEA) maka dibutuhkan peran perguruan tinggi yang mampu melahirkan peserta didik berorientasi Iptek dan Imtak, yang memiliki kemampuan dalam berbagai aspek, diantaranya adalah pendidik yang mampu memberi inspirasi kepada peserta didik untuk berpikir maju dan memiliki jiwa kompetitif dalam berbagai sendi kehidupan.

Dengan demikian, agar mutu kualitas output suatu perguruan tinggi bagus, dan agar proses peningkatan mutu tetap terkontrol, maka pada era global yang penuh dengan persaingan ini jelas diperlukan strategi manajemen pendidikan yang benar-benar tepat agar lulusan lembaga suatu perguruan tinggi hal. 107.

3 Amirudin Idris, Pengantar Ekonomi Sumber Daya Manusia, (Yogyakarta: Deepublis, 2016), RI'AYAH, Vol. 01, No. 01 Januari-Juni 2016 
memiliki daya saing yang tinggi. Tanpa adanya manajemen yang tepat niscaya akan sulit bagi lembaga pendidikan kita untuk dapat eksis terlebih survive dengan memiliki mutu yang baik. Pemikiran ini telah mendorong munculnya pendekatan baru, yakni manajemen mutu terpadu atau Total Management Quality (TQM).

Salah satu usaha perguruan tinggi yang diharapkan dapat meningkatkan mutu pengelolaanya untuk mencapai tujuannya adalah dengan menerapkan Total Quality Management (TQM). TQM ini akan berhubungan dengan sistem kualitas yang terdiri dari: perencanaan sistem kualitas, pengendalian sistem kualitas, dan peningkatan sistem kualitas. Untuk itu, dalam penelitian ini peneliti berupaya untuk menjelaskan peningkatan kualitas pendidikan di perguruan tinggi melalui TQM dalam menyongsong MEA.

Penelitian ini adalah penelitian pustaka yang bersifat deskriptif. Sumber data yang digunakan dalam penelitian adalah sumber data sekunder berupaya buku-buku dan literatur terkait dengan peningkatan kualitas pendidikan di perguruan tinggi melalui TQM dalam menyongsong MEA. Tehnik pengumpulan data dilakukan melalui dokumentasi sedangkan analisa data dalam penelitian ini dilakukan dengan content analysis, yakni dengan memanfaatkan seperangkat prosedur untuk menarik kesimpulan yang shahih dari sebuah buku atau dokumen. ${ }^{4}$

\section{Kualitas Pendidikan di Indonesia}

Kualitas merupakan suatu kondisi dinamis yang berhubungan dengan produk, jasa, manusia, proses, dan lingkungan yang memenuhi atau melebihi harapan". Secara kuantitatif dapat dikatakan bahwa pendidikan di Indonesia telah mengalami kemajuan. Indikator pencapaiannya dapat dilihat pada kemampuan baca tulis masyarakat yang mencapai $67,24 \%$. Hal ini sebagai akibat dari program pemeraaan pendidikan, teutrama melalui INPRES SD yang dibangun oleh rezim Orde Baru. Namun demikian, keberhasilan segi kualitatif pendidikan di Indonesia belum berhasil membangun karakter bangsa yang cerdas dan kreatif apalagi unggul. ${ }^{5}$

Berbicara mengenai kualitas pendidikan di Indonesia, memang selama enam Repelita telah banyak yang kita capai di dalam pelaksanaan pemeratan pendidikan. Tidak kurang dari badan PBB UNESCO dan UNDP mengakui keberhasilan Indonesia serta usaha-usaha lainnya untuk pemerataan pendidikan yang berkaitan dnegan pemnanggulangan kemiskinan. ${ }^{6}$ Namun demikian,

\footnotetext{
4 Soejono Soekanto, Metodologi Penelitian, (Jakarta: Rieneka Cipta, 2005), hal. 109.

5 Nurul Afifah, Problematika Pendidikan di Indonesia (Telaah dari Aspek Pembelajaran), dalam "JURNAL ELEMENTARY", (Lampung: STAIN Jurai Siwo Metro), Vol. 1 Januari 2015, hal. 2.

6 H.A.R. Tilaar, Beberapa Agenda Reformasi Pendidikan Nasional Dalam Perspektif Abad 21, (Magelang: Tera Indonesia, 1998), hal. 50.
}

RI'AYAH, Vol. 01, No. 01 Januari-Juni 2016 
kualitas pendidikan kita berada pada urutan 101 dan masih berada di bawah vietnam yang notabene negara tersebut dapat dikatakan baru saja merdeka dibandingkan dengan kemerdekaan bangsa kita Indonesia. Dalam hal ini, Indonesia tertinggal jauh dan harus segera mengupayakan pembenahan agar tidak semakin tertinggal jauh dengan negara lain.

Dalam rangka meningkatkan kesempatan bagi setiap anak bangsa untuk memperoleh kesempatan mengikuti pendidikan berkualitas maka diperlukan upaya yang bertujuan memeratakan kualitas pendidenarnya konsep tentang kualitas itu bersifat tidak jelas bentuknya, tak terukur, dan ambigu namun dalam konteks kebijakan publik kualitas pendidikan yang dimaksud adalah pencapaian standar pendidikan. Atas dasar ini pemerataan memperoleh pendidikan berkualitas berarti pemerataan memperoleh pendidikan yang memenuhi standar yang ditetapkan. Meskipun dalam kenyataanya sangat sulit dihindari keberagaman dalam kualitas pendidikan, namun setiap satuan pendidikan dalam sistem pendidikan nasional pada jenjang pendidikn dasar, menengah dan tinggi harus mencapai standar kualitas yang ditetapkan secara nasional mengacu pada standar nasional pendidikan. ${ }^{7}$

Di Indonesia, upaya pembangunan pendidikan juga dilakukan di berbagai jenjang, mulai dari pendidikan dasar, menengah, sampai pendidikan tinggi. Semua jenjang ini diharapakan memenuhi fungsi dan mencapai tujuan pendidikan nasional, seperti yang terdapat dalam Undang-undang Sistem Pendidikan Nasional Nomor 20 Tahun 2003 yaitu berfungsi mengembangkan kemampuan dan membentuk watak serta peradaban bangsa yang bermartabat dalam rangka mencerdaskan kehidupan bangsa; dan bertujuan untuk mengembangkan potensi peserta didik agar menjadi manusia yang beriman dan bertakwa kepada Tuhan Yang Maha Esa, berakhlak mulia, sehat, berilmu, cakap, kreatif, mandiri, dan menjadi warga Negara yang demokratis serta bertanggung jawab. ${ }^{8}$

Pendidikan dan latihan merupakan faktor penting dalam pengembangan sumber daya manusia. Pendidikan dan latihan akan menambah pengetahuan, meningkatkan keterampilan kerja, dan pada akhirnya produktivitas kerja juga akan meningkat. Hal ini terlihat dari hasil penelitian, bahwa tingkat pendidikan penduduk suatu negara yang rata-rata tinggi akan mengalami pertumbuhan ekonomi yang lebih cepat. Sehingga pendidikan dan latihan dipandang sebagai Human Investment yang imbalannya dapat diperoleh beberapa tahun kemudian. Tingkat pendidikan dan latihan yang dimiliki seorang tenaga kerja akan memberikan pengaruh terhadap produktivitas tenaga kerja tersebut.

7 Mohammad Ali, Pendidikan untuk Pembangunan Nasional: Menuju Bangsa Indonesia yang Mandiri dan Berdaya Saing Tinggi, (Jakarta: Imtima, 2009), hal. 330.

8 Kholid Musyaddad, Problematika Pendidikan Di Indonesia, dalam "Jurnal Eco-Bio Tropika", (Aceh: Universitas Syiah Kuala), Vol. 4, Tahun 2013, hal. 51.

RI'AYAH, Vol. 01, No. 01 Januari-Juni 2016 
Pendidikan yang ada di Indonesia belum sepenuhnya memberikan kontribusi kepada masyarakat melalui nilai dan manfaat pendidikan itu sendiri. Kualitas lulusan yang ada saat ini masih sangat rendah. Ini merupakan salah satu bukti bahwa selam ini pendidikan di Indonesia belum dikelola dan dikembangkan secara optimal. Relevansi pendidikan dalam hal substansi dengan kebutuhan masyarakat dinilai masih rendah. Ironisnya, pendidikan justru menjadi area politisasi dari para pejabat. Banyaknya masalah pendidikan yang muncul ke permukaan merupakan gambaran kualitas pendidikan yang harus dibenahi.

\section{Kesiapan Lulusan Perguruan Tinggi dalam Menghadapi Masyarakat Ekonomi Asean (MEA)}

Pendidikan memang merupakan salah satu sarana untuk meningkatkan mutu sumber daya manusia. Dengan pendidikan dapat ditingkatkan pengetahuan dan keterampilan yang selanjutnya akan berdampak pada produktivitas. Pendidikan dapat pula dilihat sebagai investasi sumber daya manusia dan hasilnya akan dperoleh beberapa tahun kemudian. Namun, peningkatan mutu pendidikan yang tidak diimbangi dengan tersedianya lapangan pekerjaan akan menimbulkan permasalahan baru. Walaupun saat ini ada kecenderungan bahwa sarjana lulusan perguruan tinggi lebih banyak yang menganngur daripada bekerja. Hal ini terutama disebabkan terbatasnya lapangan pekerjaan yang tersedia, padahal penuduk yang lulus perguruan tinggi setiap tahunnya selalu bertambah. Sebagai akibatnya, banyak diantara para sarjana yang bekerja pada bidang yang bukan keahliannya. Hal ini terpaksa dilakukan dnegan pertimbangan daripada menganggur. ${ }^{9}$

Dilihat dari jenjang pendidikan, jumlah angkatan kerja yang lulus sekolah menengah ke atas atau diatasnya di empat negara ASEAN mencapai rata-rata $30 \%$, kecuali Malaysia yang mencapai lebih dari $70 \%$. Di Filipina, rasio jenjang sekolah ini mencapai hampir 50\%, meskipun sistem pendidikan di Filipina sedikit berbeda dimana pelajar hanya menyelesaikan 4 tahun di sekolah menengah dan atas setelah 6 tahun di sekolah dasar. Sementara itu, jumlah nagkatan kerja yang lulus perguruan tinggi mencapai hampir 20\%. Sedangkan di Thailand, jumlah lulusan perguruan tinggi ke atas mencapai 13,6\% dari seluruh angkatan kerja. Keadaan yang snagat berbeda terjadi di Indonesia. Pada 2005, angkatan kerja yang tamat perguruan tinggi sangat rendah, hanya sekitar 5,3\% dan bahkan tampak menurut menjadi 3,6 \% pada Februari 2007. Keadaan ini sejalan dengan rasio pengeluaran masyarakat Indonesia untuk tujuan

${ }_{9}^{9}$ Amirudin Idris, Pengantar Ekonomi., hal. 125

RI'AYAH, Vol. 01, No. 01 Januari-Juni 2016 
pendidikan terhadap PDB dana mencapai level cukup rendah $(0,9 \%)$ bahkan lebih rendah dari Kamboja (2,3\%), Laos (1,9\%) dan Myanmar (1,3\%). ${ }^{10}$

Masalah SDM inilah yang menyebabkan proses pembangunan yang berjalan selama ini kurang didukung oleh produktifitas tenaga kerja yang memadai. Itu sebabnya, keberhasilan pembangunan yang selama 32 tahun dibanggakan dengan tingkat pertumbuhan rata-rata $7 \%$, hanya berasal dari pemanfaatan sumber dayaa alam intensif (hutan dan hasil tambang), arus modal asing berupa pinjaman dan investasi langsung. Dengan demikian, bukan berasal dari kemampuan manajerial dan produktivitas SDM yang tinggi. Keterpurukan ekonomi nasional yang berkepanjangan hingga kini merupakan bukti kegagalan pembangunan akibat dari rendahnya kualitas SDM dalam menghadapi persaingan ekonomi global.

Sekarang bukan saatnya bagi Indonesia membangun perekonomian dengan kekuatan asing. Tapi, sudah seharusnya bangsa indonesa secara benar dan tepat memanfaatkan potensi sumber daya yang dimiliki dengan kemampuan SDM yang tinggi sebagai kekuatan dalam membangun perekonomian nasional. ${ }^{11}$

Dengan adanya MEA 2015, maka akan terbuka kesempatan kerja seluasluasnya bagi warga negara ASEAN. Setiap warga negara di ASEAN dapat dengan mudah keluar masuk ke negara-negara MEA untuk mendapatkan pekerjaan tanpa adanya hambatan dari negara yang dituju. Pada dasarnya, semua pembahasan yang menyangkut tenaga kerja di era MEA yang telah dirumuskan dalam AEC blue print hanya terbatas pada pengaturan khusus untuk tenaga kerja terampil (skilled labour) tidak ada pembahasan menyangkut tenaga kerja tidak terampil. Seperti yang diketahui tenaga kerja terampil (skilled labour) adalah tenaga kerja yang mempunyai keterampulan dan keahlian khusus serta pengetahuan dan kemampuan di bidang-bidang tertentu. Dalam hal ini sangat jelas bahwa tenaga kerja terampil (skilled labour) yang sangat diperlukan dalam MEA sehingga lulusan perguruan tinggi harus memiliki keterampilan dan keahlian untuk memenangkan persaingan di MEA.12

Perguruan tinggi sebagai lembaga yang mengeluarkan output lulusan siap kerja, harusnya mengupayakan agar lulusan memiliki daya saing yang tinggi hingga tidak kalah bersaing dengan lulusan-lulusan dari perguruan tinggi lain bahkan dari negara lain. Perguruan tinggi harus membuat lulusannya memiliki kemampuan lebih dibandingkan dnegan perguruan tinggi lain. Bila selama ini banyhak lulusan dari perguruan tinggi yang menganggur, itu berarti perguruan tinggi tempat lulusan tersebut mengenyam pendidikan belum memberikan apa yang dibutuhkan oleh dunia kerja. Oleh sebab itu, dengan berlakunya MEA,

$10 \mathrm{Ibid}$, hal. 126.

11 Ibid.

12 Chichi Andriani, Mahasiswa dan Perguruan Tinggi., hal. 286.

RI'AYAH, Vol. 01, No. 01 Januari-Juni 2016 
perguruan tinggi diharapkan lebih tegas lagi dalam menyiapkan lulusanlusannya yang akan menghadapi dunia kerja. Persaingan yang akan dihadapi bukan lagi sekedar antar perguruan tinggi, melainkan antar negara.

\section{Konsep Total Quality Management (TQM)}

Total Quality Management (TQM) dapat didefinisikan dari tiga kata yang dimilikinya yaitu: Total (keseluruhan), Quality (kualitas, derajat/tingkat keunggulan barang atau jasa), Management (tindakan, seni, cara menghendel, pengendalian, pengarahan). Dari ketiga kata yang dimilikinya, definisi TQM adalah: "sistem manajemen yang berorientasi pada kepuasan pelanggan (customer satisfaction) dengan kegiatan yang diupayakan benar sekali (right first time), melalui perbaikan berkesinambungan (continousimprovement) dan memotivasi karyawan. ${ }^{13}$

Menurut Hadari Nawari, Total Quality Management (TQM) adalah manejemen fungsional dengan pendekatan yang secara terus menerus difokuskan pada peningkatan kualitas, agar produknya sesuai dengan standar kualitas dari masyarakat yang dilayani dalam pelaksanaan tugas pelayanan umum (public service) dan pembangunan masyarakat (community development). Konsepnya bertolak dari manajemen sebagai proses atau rangkaian kegiatan mengintegrasikan sumber daya yang dimiliki, yang harus diintegrasi pula dengan pentahapan pelaksanaan fungsi - fungsi manajemen, agar terwujud kerja sebagai kegiatan memproduksi sesuai yang berkualitas. Setiap pekerjaan dalam manajemen mutu terpadu harus dilakukan melalui tahapan perencanaan, persiapan (termasuk bahan dan alat), pelaksanaan teknis dengan metode kerja/cara kerj yang efektif dan efisien, untuk menghasilkan produk berupa barang atau jasa yang bermanfaat bagi masyarakat. ${ }^{14}$

Menurut Marimin, Total Quality Management (TQM) adalah sistem manajemen yang mengikutsertakan seluruh anggota organisasi dalam menerapkan konsep dan teknik kendali mutu untuk mendapatkan kepuasan pelanggan dan orang yang mengerjakannya. ${ }^{15}$

TQM merupakan sistem manajemen yang mengangkat kualitas sebagai strategi usaha dan berorentasi pada kepuasan pelanggan dengan melibatkan seluruh anggota organisasi. Total Quality Management merupakan suatu pendekatan dalam menjalankan usaha yang mencoba untuk memaksimumkan

13 Zulian Yamit, Manajemen Kualitas Produk Dan Jasa, (Yogyakarta: dipura, 2001), hal. 181.

14 Hadari Nawawi, Manajemen Strategik, (Yogyakarta: Gadjah Mada Pers, 2005), hal. 46

15 Marimin, Teknik dan Aplikasi Pengambilan Keputusan Kriteria Majemuk, (Jakarta: PT Gramedia Widiasarana Indonesia, 2004), hal. 32.

RI'AYAH, Vol. 01, No. 01 Januari-Juni 2016 
daya saing organisasi melalui perbaikan terus menerus atas produk, jasa, manusia, proses dan lingkungannya. ${ }^{16}$

Program TQM adalah program organisasi secara menyeluruh yang mengintegrasikan semua fungsi dan proses bisnis meliputi perancangan, perencanaan, produksi, distribusi, distribusi, jasa yang bertujuan untuk memaksimalisasi kepuasan pelanggan melaluiperbaikan secara terus-menerus. Program demikian dibangun atas beberapa prinsip, yaitu ketergantungan pada inspeksi untuk mencapai kualitas, pebaikan secara kontinyu, on the job training secara ekstensif, hilangkan ketakutan sehingga setiap orang dapat bkerja secara efektif dan hilangkan hambatan antara departemen, perbaikan diri sendiri dan lain-lain. ${ }^{17}$

Prinsip-prinsip TQM ini dapat diterapkan untuk merancang sistem penilaian prestasi, dimana dalam penilaian itu manajer tidak dipaksakan untuk memberikan ukuran yang tidak tepat atau salah, tetapi menyediakan diskusi terbuka dan berkaitan dengan pekerjaan di antara atasan dan bawahan. ${ }^{18}$

\section{Total Quality Management (TQM) sebagai Solusi Peningkatan Kualitas Pendidikan}

Faktor determinan yang paling menentukan rendah tidaknya kualitas perguruan tinggi terletak pada manajemen perguruan tinggi. Manajemen perguruan tinggi terletak pada kemampuan mengelola perguruan tinggi secara integral dan menyeluruh dengan mengoptimalkan alokasi dan pemanfaatan sumber daya yang dimiliki perguruan tinggi, tidak akan berdaya guna jika tidak dikelola melalui manajemen perguruan tinggi. Optimalisasi sumber daya pada perguruan tinggi memerlukan kualitas (skil). Skill inilah yang secara sederhana menjadi unsur utama pada manajemen perguruan tinggi. Penerapan manajemen perguruan tinggi yang baik akan menghasilkan output berkualitas, sedangkan manajemen yang tidak baik akan menghasilkan output yang tidak berkualitas. ${ }^{19}$

Perguruan tinggi sebagai organisasi memerlukan leadership dan manajemen. Leadership dan manajemen perguruan tinggi difokuskan pada Tri Dharma Perguruan Tinggi yaitu pendidikan -pengajaran, penelitian dan pengabdian pada masyarakat. ${ }^{20}$ Perguruan tinggi harus menjalani ketiga peran ini seklaigus, oleh sebab itu dibutuhkan leadhership dan manajemen yang baik agar ketiga peran ini dapat berjalan dengan baik. Salah satu pendekatan yang

16 Fandy Tjiptono \& Anastasia Diana, Total Quality Management, (Yogyakarta: Penerbit ANDI, 2003), hal. 7.

17 Justine T. Sirait, Memahami Aspek Pengelolaan SDM dalam Organisasi, (Jakarta: Grasindo, 2006), hal. 158.

18 Ibid.

${ }^{19}$ Hasballah Taib, Prof. Chairuddin P. Lubis dalam Pandangan Ulama dan Cendikiawan, (Medan: USU Press, 2009), hal. 78.

${ }^{20}$ Ibid.

RI'AYAH, Vol. 01, No. 01 Januari-Juni 2016 
dapat digunakan oleh leader dan manajemen untuk dapat menjalankan Tri Dharma Perguruan Tinggi sekaligus meningkatkan kualitas mutu pendidikan di perguruan tinggi adalah dengan Total Quality Management (TQM).

Total Quality Management (TQM) dalam bidang pendidikan memiliki tujuan akhir meningkatkan kualitas, daya saing bagi output (lulusan) dengan indikator adanya kompetensi baik intelektual maupun skill serta kompetensi sosial siswa/lulusan yang tinggi. Dalam mencapai hasil tersebut, implementasi TQM di dalam organisasi pendidikan perlu dilakukan dengan sebenarnya tidak dengan setengah hati. Dengan memanfaatkan semua entitas kualitas yang ada dalam organisasi maka pendidikan kita tidak akan jalan di tempat seperti saat ini.

Implementasi TQM di organisasi Pendidikan khususnya negeri memang tidak mudah. Adanya hambatan dalam budaya kerja, unjuk kerja dari guru dan karyawan sangat mempengaruhi. Tidak perlu dipungkiri bahwa budaya kerja, unjuk kerja dan disiplin pegawai negeri sipil di negara kita ini sangat rendah. Ini sangat mempengaruhi efektifitas implementasi TQM.

Yang paling pertama diperbaiki adalah budaya kerja, unjuk kerja dan disiplin dari pelaksana perguruan tinggi (dosen, karyawan dan pimpinan). Semuanya harus dapat memandang mahasiswa sebagai "pelanggan", yang harus dilayani dengan sebaik - baiknya demi kepuasan mereka. Pelaksana perguruan tinggi dalam hal ini harus selalu bersemangat untuk maju, menambah kemampuan dan ketrampilannya yang pada akhirnya akan meningkatkan unjuk kerja mereka di hadapan mahasiswa. Bila semua pihak telah memiliki budaya kerja, unjuk kerja dan disiplin yang tinggi, maka implementasi TQM dapat secara nyata berjalan dan akan menjadikan suatu perguruan tinggi semakin maju, eksis, memiliki brand image yang semakin tinggi dan pada akhirnya dapat menciptakan generasi penerus bangsa yang berkualitas dan dapat bersaing dengan bangsa lain. ${ }^{21}$

Perguruan Tinggi harus mengidentifikasikan kebutuhannya dan merumuskan visi, misi, dan tujuan dalam rangka menyajikan pendidikan yang berkualitas bagi siswanya sesuai dengan konsep pembangunan pendidikan nasional yang akan dicapai. Hal penting yang perlu diperhatikan sehubungan dengan identifikasi kebutuhan dan perumusan visi, misi dan tujuan adalah bagaimana siswa belajar penyediaan sumber daya dan pengeloaan kurikulum termasuk indikator pencapaian peningkatan mutu tersebut.

Dalam perguruan tinggi juga masih terjadi perbedaan pendapat tentang posisi mahasiswa, apakah dimasukan sebagai produk atau sebagai pelanggan. Hal ini menjadi masalah dalam aplikasi prinsip TQM, terutama dalam hubungan

${ }^{21}$ Muhammad Khoiri, Upaya Peningkatan., hal. 40.

RI'AYAH, Vol. 01, No. 01 Januari-Juni 2016 
antara dosen dan mahasiswa. Secara alamiah dunia akademik bebas dari masalah pemasaran (independent of market issues), hal ini bisa menimbulkan dampak negatif akibat melupakan kebutuhan pelanggan yang nyata. Tetapi satu hal yang perlu diingat adalah kesuksesan pelajar/mahasiswa adalah kesuksesan institusi pendidikannya. ${ }^{22}$

Dalam menghadapi MEA, sumber daya manusia yang ada saat ini memang dirasa belum mampu untuk bersaing dnegan negara-negara lain. Untuk itu, perguruan tinggi harus menggembleng mahasiswa-mahasiswanya agar ketika ia keluar sebagai lulusan, ia sudah siap dan mampu memberi kontribusi pembangunan negara. Lulusan perguruan tinggi harus menjadi sumber daya manusia yang unggul dan harus mempunyai kelebihan dengan sumber daya manusia lainnya. Lulusan perguruan tinggi harus mampu berperan menjadi penggerak pembangunan bangsa, harus mampu mempraktekkan teori yang telah dipelajari terhadap masalah-masalah yang dihadapi di masyarakat, sehingga bisa berfikir kritis dalam menyelesaikan permasalahan serta memberikan solusi yang dihadapi masyarakat.

Penyelesaian masalah pendidikan, khusunya mengenai sumber daya manusia yang masih rendah tidak semestinya dilakukan secara terkotak-kotak. Tetapi harus di tempuh dalam suatu tindakan yang menyeluruh. Misalnya jika pemerintah hanya menaikkan anggaran, tetapi sumber daya dan mutu pendidikan masih rendah, maka apa yang diharapkan tidak akan tercapai. ${ }^{23}$

Agar suatu organisasi pendidikan dapat memiliki keunggulan dalam skala global, maka organisasi pendidikan tersebut harus mampu melakukan pengelolaan secara lebih baik dalam rangka menghasilkan lulusan yang berkualitas tinggi dengan biaya yang wajar dan bersaing. Dengan kata lain, dalam persaingan global yang modern, kunci untuk meningkatkan daya saing adalah kualitas. ${ }^{24}$

Bila kita melirik dunia kerja saat ini, masih banyak terjadi kesenjangan kualifikasi lulusan perguruan tinggi dengan kebutuhan indutri, terutama dalam hal kemampuan solusi masalah berdasarkan konsep ilmiah dan ketrampilan kelompok (teamwork) dimana di perguruan tinggi masih banyak yang mementingkan teori dan asal lulus ujian serta hanya menekankan ketrampilan individual. Padahal yang dibutuhkan dunia kerja bukanlh ijazah yang asal lulus, melainkan harus memiliki ketrampilan yang cukup dan dapat bersaing dalam dunia kerja. Oleh sebab itu, harus ada standar minimum yang harus dipenuhi lulusan perguruan tinggi agar mampu lulusan tersebut tidak bingung ketika ia sudah memasuki dunia kerja. Selain itu, perguruan tinggi juga harus secara terus-menerus meningkatkan standar lulusan sejalan dengan tuntutan pasar

22 Ibid.

${ }^{23}$ Kholid Musayyad, Problematika Pendidikan., hal. 53.

${ }^{24}$ Muhammad Khoiri, Upaya Peningkatan., hal. 38.

RI'AYAH, Vol. 01, No. 01 Januari-Juni 2016 
tenaga kerja yang semakin kompetitif. Secara otomatis, semakin lama, standar lulusannya akan semakin tinggi.

Umumnya, kegiatan dalam suatu organisasi termasuk perguruan tinggi terbagi ke dalam dua kegiatan, yaitu kegiatan kegiatan manajemen-administrasi dan akademik. Untuk bidang manajemen-administrasi maka perguruan tinggi bisa disamakan dengan industri jasa, sehingga prinsip-prinsip TQM untuk industri jasa bisa langsung diterapkan di bidang ini. Untuk bidang akademik, diantaranya proses belajar-mengajar, dimana ada prinsip kebebasan akademik serta hubungan mahasiswa-dosen yang tidak bisa mutlak diartikan yang dilayani dan yang melayani. Demikian juga secara alamiah proses pencarian dan pemberian ilmu sangat dipengaruhi oleh budaya yang berkembang dan juga masih terjadi perbedaan pendapat tentang posisi mahasiswa, apakah dimasukkan sebagai produk atau sebagai pelanggan. Masing-masing perguruan tinggi harus mengembangkan sistem TQM-nya sendiri-sendiri. Walau demikian perguruan tinggi harus tetap berorientasi kepada kualitas/mutu lulusannya, sehingga bisa diterima pelanggan eksternal. Setiap perusahaan adalah pelanggan bagi pemasoknya dan pemasok bagi pelanggannya, sehingga pemikiran perusahan harus meliputi sebagai pelanggan dan sebagai pemasok. ${ }^{25}$

Pelanggan dalam dunia pendidikan adalah pengelola institusi pendidikan itu sendiri, misalkan manajer, guru/dosen, staff, dan penyelenggara institusi. Sedangkan yang termasuk pelanggan luar adalah pelajar/mahasiswa, masyarakat, pemerintah, dan dunia industri, dimana pelajar/mahasiswa adalah pelanggan utama. Disamping harus memahami pelanggan, maka untuk dapat memahami mutu juga harus memahami produk yang dihasilkan. Untuk dapat mendifinisikan produknya maka pendidikan dipandang sebagi sebuah jasa atau layanan dan bukan sebuah bentuk produksi.

Salah satu tujuan TQM adalah untuk merubah institusi yang mengoperasikannya menjadi sebuah tim yang ikhlas, tanpa konflik dan kompetisi internal, untuk meraih sebuah tujuan tunggal, yaitu memuaskan pelanggan. ${ }^{26}$ Konsep TQM telah terinfusi dalam definisi ISO 8402 pada tahun 1994 dan dikenal sebagai metode pendekatan manajemen operasional yang berbasis pada kualitas dengan partisipasi seluruh anggota organisasi dengan fokus pada kepuasan onsumen sebagai tujuan aktivitas operasional kerja. Prinsip-prinsip yang mendasari paradigma TQM terbagi menjadi tiga bagian yaitu:

1. Model keanggotaan dalam aktivitas operasional kerja yang diekspresikan dalam bentuk desain personil dalam berbagai level/tingkatannya yang disebut dengan 'struktur operasional kerja';

${ }^{25}$ Ibid., hal. 40 .

26 Ibid.

RI'AYAH, Vol. 01, No. 01 Januari-Juni 2016 
2. Kepemimpinan yang kuat dari pereanan manajemen puncak yang digambarkan dalam fungsi-fungsi manajemen edukasi/pembelajaran, dan manajemen pelatihan bagi segenap anggota organisasional keja;

3. Metode pengembangan dan peningkatan kualitas yang diterapkan diseluruh aktivitas manajerial bertujuan untuk membangun komitmen dan mencapai tujuan organisasional kerja. ${ }^{27}$

Berdasarkan hal tersebut, dapat kita tarik benang merah bahwa terdapat struktur operasional kerja yang betujuan agar setiap bagian kerja dapat memaksimalkan tugas dan fungsinya masing-masing. Sejauh ini, telah terbukti bahwa peran karyawan, hubungan pimpinan dan karyawan, aspek organisasi, dan aspek lingkungan berpengaruh terhadap kemampuan teoritis, teknis, konseptual, moral, dan kualitas sumber daya manusia. Hal ini akan berpangaruh positif terhadap kepuasan pekerja, yang akan berakibat pada naiknya loyalitas karyawan. Untuk itu, dalam TQM, peran top management sangat menentukan kebarhasilan TQM.

Setelah TQM diaplikasikan maka perlu adanya Quality Assurance. Quality Assurance merupakan bagian yang tidak terpisahkan dalam manejemen pendidikan tinggi berbasiskan mutu keluaran harus melibatkan semua aspek manajemen pendidikan tinggi. Baik aspek pengelolaan akademik maupun aspek penunjangnya. Kita menyadari bahwa performance suatu organisasi adalah performance dari mata ranta terlemah. Dengan demikian, manajemen harus selalu melakukan assesement untuk mencari tahu mata rantai terlemah itu. Kemudian melaksanakan perlakuan khusus untuk memperbaikinya. ${ }^{28}$

Elemen-elemen yang ditekankan dalam quality assurance untuk perguruan tinggi, yang meliputi: (1) Visi, misi, sasaran (2) Desain program pendidikan dan metodologi belajar-mengajar (3) Penilaian mahasiswa (4) Sistem pendukung dan seleksi mahasiswa (5) Staf akademik (6) Sumber daya kependidikan (7) Evaluasi program (8) Kepemimpinan dan pejabat (9) Peningkatan kualitas secara kontinyu. ${ }^{29}$

Ada beberapa hal yang harus diperhatikan dalam pelaksanaan TQM. Pertama, pelaksanaan TQM harus dilakukan secara kontinyu dan terus menerus dengan berbagai evaluasi. Artinya, bahwa suatu perguruan tinggi harus berupaya untuk memperbaharui pengimplementasian TQM dan melakukan evaluasi secara terus menerus untuk mencapai standar mutu berdasarkan kebutuhan dan tuntutan menghasilkan lulusan yang mampu berkompetisi

27 Anang Hidayat, Stategi Six Sigma: Peta Pengembangan Kerja dan Kualitas Bisnis, (Jakarta: Elexmedia Komputindo, 2007), h. 153.

28 Afriantoni,Edy Karno,E. Hamzah Suaidi, Isu-Isu Kritis dalam Pendidikan Tinggi: Sebuah Tinjauan Aktual terhadap Praktik Pendidikan Tinggi di Indonesia, (Yogyakarta: Deepublish, 2016), hal. 75 .

${ }^{29}$ Muhammad Khoiri, Upaya Peningkatan., hal. 41.

RI'AYAH, Vol. 01, No. 01 Januari-Juni 2016 
dengan lulusan perguruan tinggi dalam menghadapi MEA. Kedua, perguruan tinggi harus membuat quality assurance, terutama dalam hal kurikulum, proses pembelajaran, dan kemudian mengevaluasinya. Ketiga, pihak-pihak yang ada dalam perguruan tinggi harus senantiasa menjaga hubungan yang baik antar sesama pihak yang ada dalam struktur operasional kerja maupun dengan pelanggannya. Antara sesama pihak harus saling menghormati dan menghargai sekecil apapun peningkatan dan prestasi. Menjadikan sebuah perguruan tinggi menjadi sebuah lembaga yang menghasilkan output berdaya saing tinggi bukanlah hal yang mudah. Terlebih setelah berlakunya MEA. Perguruan tinggi dituntut untuk melakukan perbaikan dari berbagai sisi. Dalam melakukan perbaikan ini, khususnya dengan menggunakan TQM, pasti ada hambatanhambatan yang akan dihadapi perguruan tinggi. Untuk itu, diperlukan evaluasi dan perbaikan yang terus-menerus serta kesabaran dan motivasi tinggi supaya ketika berupaya menyiapkan lulusan dan meningkatkan kualitas pendidikan, perguruan tinggi tidak mengalami kejenuhan, sehingga dapat mengahasilkan lulusan yang memiliki kualitas tinggi dan dapat bersaing dalam menghadapi MEA.

\section{Penutup}

MEA 2015 merupakan kesepakatan yang tak hanya berdampak pada sektor ekonomi saja, melainkan juga sektor-sektor lainnya, termasuk sektor pendidikan. Pendidikan adalah lokomotif pembangunan manusia. Oleh sebab itu peningkatan kualitas Sumber Daya Manusia (SDM) terutama yang merupakan lulusan pergutuan Tinggi harus digalakkan. Perguruan Tinggi sebagai lembaga yang menghasilkan lulusan-lusan siap kerja setiap tahunnya, harus menyiapkan lulusan yang memiliki hard skill dan soft kill lulusannya. Pendidikan di Perguruan Tinggi harus berorientasi pada kompetensi yang dibutuhkan oleh dunia kerja karena persentase penganggur di kalangan terdidik terus meningkat.

Apabila TQM pada perguruan tinggi diterapkan dan dijalankan secara kontinyu dan konsisten maka kualitas lulusannya kan semakin meningkat, dalam arti telah mampu dan siap bersaing untuk memasuki dunia kerja industri. Keberhasilan TQM sangat tergantung komitmen dan kualitas pimpinan atau manajemen baik level atas maupun menengah. Selain itu, untuk memancing penerapan TQM di Perguruan Tinggi perlu dilakukan dengan memberikan penghargaan dan anugerah kepada perguruan tinggi yang berhasil melaksanakan TQM dengan baik.

RI'AYAH, Vol. 01, No. 01 Januari-Juni 2016 


\section{Daftar Pustaka}

Afriantoni,Edy Karno,E. Hamzah Suaidi, Isu-Isu Kritis dalam Pendidikan Tinggi: Sebuah Tinjauan Aktual terhadap Praktik Pendidikan Tinggi di Indonesia, Yogyakarta: Deepublish, 2016.

Amirudin Idris, Pengantar Ekonomi Sumber Daya Manusia, Yogyakarta: Deepublis, 2016

Anang Hidayat, Stategi Six Sigma: Peta Pengembangan Kerja dan Kualitas Bisnis, Jakarta: Elexmedia Komputindo, 2007.

Chici Andriani, Mahasiswa dan Perguruan Tinggi dalam Era ASEAN Economic Community 2015, Seminar Ekonomi Manajemen dan Akutansi (SNEMA) Fakultas Ekonomi Universitas Negeri Padang, h. 284. Dapat Diakses Melalui http://fe.unp.ac.id/

Fandy Tjiptono \& Anastasia Diana, Total Quality Management, (Yogyakarta: Penerbit ANDI, 2003.

H.A.R. Tilaar, Beberapa Agenda Reformasi Pendidikan Nasional Dalam Perspektif Abad 21, Magelang: Tera Indonesia, 1998.

Hadari Nawawi, Manajemen Strategik, Yogyakarta: Gadjah Mada Pers, 2005.

Hasballah Taib, Prof. Chairuddin P. Lubis dalam Pandangan Ulama dan Cendikiawan, Medan: USU Press, 2009.

Justine T. Sirait, Memahami Aspek Pengelolaan SDM dalam Organisasi, Jakarta: Grasindo, 2006.

Kholid Musyaddad, Problematika Pendidikan Di Indonesia, dalam “Jurnal Eco-Bio Tropika", Aceh: Universitas Syiah Kuala, Vol. 4, Tahun 2013.

Marimin, Teknik dan Aplikasi Pengambilan Keputusan Kriteria Majemuk, (Jakarta: PT Gramedia Widiasarana Indonesia, 2004.

Mohammad Ali, Pendidikan untuk Pembangunan Nasional: Menuju Bangsa Indonesia yang Mandiri dan Berdaya Saing Tinggi, Jakarta: Imtima, 2009.

Nurul Afifah, Problematika Pendidikan di Indonesia (Telaah dari Aspek Pembelajaran), dalam "JURNAL ELEMENTARY", Lampung: STAIN Jurai Siwo Metro, Vol. 1 Januari 2015.

Zulian Yamit, Manajemen Kualitas Produk Dan Jasa, Yogyakarta: dipura, 2001.

RI'AYAH, Vol. 01, No. 01 Januari-Juni 2016 